\title{
Evidence for the onset of mining activities during the 13th century in Poland using lead isotopes from lake sediment cores
}

Article

Accepted Version

Creative Commons: Attribution-Noncommercial-No Derivative Works 4.0

Babos, H. B., Black, S., Pluskowski, A., Brown, A., Rohrssen, M. and Chappaz, A. (2019) Evidence for the onset of mining activities during the 13th century in Poland using lead isotopes from lake sediment cores. Science of the Total Environment, 683. pp. 589-599. ISSN 0048-9697 doi:

https://doi.org/10.1016/j.scitotenv.2019.05.177 Available at https://centaur.reading.ac.uk/83776/

It is advisable to refer to the publisher's version if you intend to cite from the work. See Guidance on citing.

To link to this article DOI: http://dx.doi.org/10.1016/j.scitotenv.2019.05.177

Publisher: Elsevier

All outputs in CentAUR are protected by Intellectual Property Rights law, including copyright law. Copyright and IPR is retained by the creators or other copyright holders. Terms and conditions for use of this material are defined in the End User Agreement. 


\section{CentAUR}

Central Archive at the University of Reading

Reading's research outputs online 


\section{Accepted Manuscript}

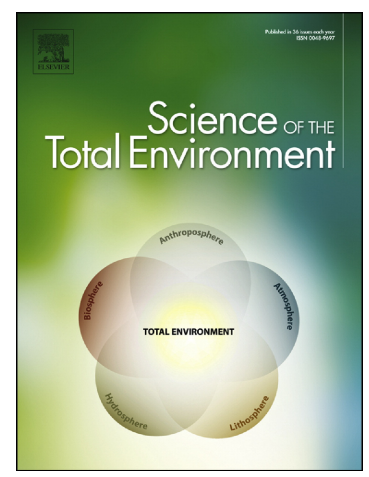

Heidi B. Babos, Stuart Black, Aleks Pluskowski, Alex Brown, Megan Rohrssen, Anthony Chappaz

Evidence for the onset of mining activities during the 13th century in Poland using lead isotopes from lake sediment cores

PII: S0048-9697(19)32210-7

DOI: https://doi.org/10.1016/j.scitotenv.2019.05.177

Reference: STOTEN 32338

To appear in: Science of the Total Environment

Received date: 29 January 2019

Revised date: 12 May 2019

Accepted date: 13 May 2019

Please cite this article as: H.B. Babos, S. Black, A. Pluskowski, et al., Evidence for the onset of mining activities during the 13th century in Poland using lead isotopes from lake sediment cores, Science of the Total Environment, https://doi.org/10.1016/ j.scitotenv.2019.05.177

This is a PDF file of an unedited manuscript that has been accepted for publication. As a service to our customers we are providing this early version of the manuscript. The manuscript will undergo copyediting, typesetting, and review of the resulting proof before it is published in its final form. Please note that during the production process errors may be discovered which could affect the content, and all legal disclaimers that apply to the journal pertain. 


\title{
Evidence for the onset of mining activities during the $13^{\text {th }}$ century in Poland using lead isotopes from lake sediment cores
}

Heidi B. Babos ${ }^{\mathrm{a}, \mathrm{b}}$, Stuart Black ${ }^{\mathrm{b}}$, Aleks Pluskowski ${ }^{\mathrm{b}}$, Alex Brown ${ }^{\mathrm{b}}$, Megan Rohrssen $^{\mathrm{a}}$, Anthony Chappaz $^{\mathrm{a}}$

${ }^{a}$ Department of Earth and Atmospheric Science, Central Michigan University, Mt. Pleasant, MI, USA

${ }^{\mathrm{b}}$ Department of Archaeology, School of Archaeology, Geography and Environmental Sciences, University of Reading, Whiteknights, Reading, Berkshire, UK

Corresponding author: anthony.c@cmich.edu

\begin{abstract}
Efforts to study how human activities have influenced the environment since the end of the Roman period to present day are lacking for North Central Europe. Here, we present new lead $(\mathrm{Pb})$ isotope data determined from two sediment cores collected from ancient lakes spanning the last 1,500 years, located in the Kuyavian-Pomeranian Voivodeship, Poland. Study sites at Radzyń Chełmiński and Rywałd were used to differentiate Pb sources. Radzyń Chełmiński is located in the vicinity of a late Medieval Teutonic Order castle and town, while Rywałd is situated within a relatively pristine area until the $19^{\text {th }}$ century when it became used for agricultural purpose. Core samples were analyzed for $\mathrm{Pb}$ concentration and isotopes $\left({ }^{206} \mathrm{~Pb}\right.$, ${ }^{207} \mathrm{~Pb},{ }^{208} \mathrm{~Pb}$ ). Bayesian modelling was used to isolate the anthropogenic signal at each site over time.
\end{abstract}


For both sites, $\mathrm{Pb}$ enrichment factors relative to titanium (Ti) and upper continental crust values range from 13 to 159 . Lead isotopic ratios range from background, pre-anthropogenic local values $\left({ }^{206} \mathrm{~Pb} /{ }^{207} \mathrm{~Pb}=1.31 \pm 0.03 \%\right.$, ${ }^{208} \mathrm{~Pb} /{ }^{206} \mathrm{~Pb}=1.97 \pm 0.04 \%$ ) to anthropogenic values (SW Poland coal, ore, slag ${ }^{206} \mathrm{~Pb} /{ }^{207} \mathrm{~Pb}=1.17 \pm 0.01 \%$, ${ }^{208} \mathrm{~Pb} /{ }^{206} \mathrm{~Pb}=2.09 \pm 0.01 \%$ ). Modeled anthropogenic contribution varies greatly over time, ranging from 14 to $100 \%$. At Radzyń Chełmiński, modeled anthropogenic $\mathrm{Pb}$ contribution and measured $\mathrm{Pb}$ concentration follow similar trends. However, at Rywałd, from around A.D.1000 to A.D. 1400 these profiles diverge significantly. Our new insights highlight different sources of Pb from the $12^{\text {th }}$ century to present day: (1) short range agricultural activities from the town, and (2) long range mining activities. Additionally, prior to the $12^{\text {th }}$ century, our data suggest continental anthropogenic activity possibly favored by a warmer climate.

\section{KEYWORDS \\ Lead - Isotopes - Sediments - Anthropogenic - Sources - Medieval}

\section{INTRODUCTION}

Lead $(\mathrm{Pb})$ is a toxic, non-essential, trace element particularly useful for tracking anthropogenic input in environmental archives (e.g. Lanphear et al., 2005). Using Pb isotopes, we can differentiate between anthropogenic (industrial and mining activities, coal and fuel burning; e.g. Cheng and $\mathrm{Hu}, 2010$ ) and natural sources (i.e. natural weathering processes) that release $\mathrm{Pb}$ into the environment (Grousset et al., 1994; Thevenon et al., 2011; Zohar et al., 2014); 
and as a result, hypothesize on the timing and locations of past human activities (Fagel et al., 2014; Hosono et al., 2016; Zohar et al., 2014).

Three radioisotopes $\left({ }^{206} \mathrm{~Pb},{ }^{207} \mathrm{~Pb},{ }^{208} \mathrm{~Pb}\right)$ are commonly measured for this type of study (Alfonso et al., 2001; Komarek et al., 2008; Reimann et al., 2012). Due to the durations of their half-lives, these isotopes are considered meta-stable in geologically recent sediment (e.g. Russell and Farquhar, 1960). There are no known environmental or industrial processes that fractionate $\mathrm{Pb}$ isotopes, and thus the isotopic composition of $\mathrm{Pb}$ is affected by $\mathrm{Pb}$ source and geologic location (Cheng and Hu, 2010; Doe, 1970; Flegal and Smith, 1995). Additionally, Pb is relatively stable within the sediment column and not readily susceptible to remobilization by early diagenetic processes or biological activities (Audry et al., 2011; Gallon et al., 2004; Harlavan, 1998; Huerta-Diaz, 1998; McIntyre and Gueguen, 2013; Schultz et al., 1987; Tessier et al., 1996; ). By analyzing ratios of these three isotopes: ${ }^{206} \mathrm{~Pb} /{ }^{207} \mathrm{~Pb}$ and ${ }^{208} \mathrm{~Pb} /{ }^{206} \mathrm{~Pb}$, it is possible to assess how source contributions of $\mathrm{Pb}$ have changed over time for a given location (Baron et al., 2006; Harlavan et al., 2010; Zohar et al., 2014).

Within the environment, $\mathrm{Pb}$ isotope ratios may be influenced by local, regional, or global sources (e.g. Choi et al., 2007, Martinez Cortizas et al., 2002, 2016, Mil-Homens et al., 2013, 2017). For example, In the Iberian Peninsula a number of studies have used $\mathrm{Pb}$ isotope ratios to document evidence of regional metallurgy and mining from the Chalcolithic $(\sim 3000 \mathrm{BC})$ to modern period (last 200 years; Martinez Cortizas et al., 2002, 2016, Mil-Homens et al., 2013). In marine sediment within the Portuguese Margin, $\mathrm{Pb}$ isotope ratios were also able to record Roman and modern mining activities from the adjacent Iberian region (Mil-Homens et al., 2017, (Include examples from above refs.) Global signatures from atmospheric transport and deposition of $\mathrm{Pb}$, such as Saharan dust storms, and leaded gasoline emissions in modern times, 
has also been documented (e.g. Bi et al., 2017, Mil-Homens et al., 2017, Shotyk et al., 1998). For this study, regional sources are defined as mining of coal ore, smelting, and leaded gasoline exhaust. Historical mining activities 300 to $500 \mathrm{~km}$ to the southwest of the study site may have introduced $\mathrm{Pb}$ to the atmosphere, allowing for transport downwind to the study site. This $\mathrm{Pb}$ transported over long range is deposited, via association with sinking particles, in lake and peat sediments (e.g. Novak et al., 2003). Local sources, on the scale of kilometers or less, can also contribute to $\mathrm{Pb}$ enrichments and/or changes in the $\mathrm{Pb}$ isotope ratios in sediments. They include enhanced weathering and erosion of the surrounding landscape due to agricultural activities, building development, metalwork, and domestic coal burning.

Regional patterns of $\mathrm{Pb}$ transport are of particular interest in Poland due to Poland's unique climatic signal in comparison to the rest of Europe, which is sensitive to both oceanic and continental influences (e.g. Zamoyski, 1987). Specifically, the Medieval Warm Period (MWP) ended in Poland earlier than the rest of Europe (Medieval Warm Period: MWP; A.D. 800 to 1300; e.g. De Vleeschouwer et al., 2009a). The portion of the MWP that influenced Poland is known as the Climatic Optimum in Poland (COP, A.D. 800 to 1150; e.g. Pluskowski, 2013). These climatic patterns may have played two non-mutually exclusive impacts on anthropogenic $\mathrm{Pb}$ contributions: directly by impacting efficiency of atmospheric $\mathrm{Pb}$ long range transport from mining regions, and indirectly through changes in human activity at the vicinity of our study sites associated with these climatic changes.

Historical $\mathrm{Pb}$ contamination associated with mining activities in Poland has been documented. The Rudawy Janowickie Mountains of Silesia, in Southwestern Poland were heavily mined for coal, copper $(\mathrm{Cu})$, iron $(\mathrm{Fe})$, silver $(\mathrm{Ag})$, and zinc-lead $(\mathrm{Zn}-\mathrm{Pb})$ ores (e.g. Cabala et al., 2013; Kierczak et al., 2013; Rybicka, 1996). There is historical documentation of 
ore mining since the $12^{\text {th }}$ century, but there may have been mining activity as early as the $5^{\text {th }}$ century A.D. (Ciarkowska et al., 2016; Kierczak et al., 2013; Kylander et al., 2005; Tyszka et al., 2012). Mining activities were recorded as $\mathrm{Pb}$ isotopic ratios and other trace element concentrations in Baltic Sea sediment from the $12^{\text {th }}$ to $17^{\text {th }}$ century A.D. (Zaborska, 2014), and in a bog located in Northern Poland (De Vleeschouwer et al, 2009a, b) from the $9^{\text {th }}$ to $18^{\text {th }}$ century A.D.

Previous studies throughout Europe measured $\mathrm{Pb}$ isotopes in lake and bog sediment to estimate the importance and origin of anthropogenic $\mathrm{Pb}$ (e.g. Martínez Cortizas et al., 2002). Sedimentary records from lake and wetland systems act as environmental archives for local and regional anthropogenic activity over time. Ideal study sites for differentiating between local and regional, anthropogenic and non-anthropogenic $\mathrm{Pb}$ sources comprise at least two nearby locations: one rural (relatively pristine) and a second that was influenced by documented human activities. Previous results obtained from sedimentary cores using $\mathrm{Pb}$ isotopes from A.D. 500 (post Roman period) to around A.D. 1800 (pre-Industrial Revolution) focus on Western and Central Europe. The few previous studies based to the east of Germany analyzed sediment samples from mountainous regions (Monna et al., 2000; Shotyk, 1998; Véron et al., 2014) and the Baltic Sea (Zillen et al, 2012). Only one study in Northern Poland aimed to track solely regional signals of coal and mining from Southwest Poland (De Vleeschouwer et al., 2009b).

No known high temporal resolution data has been previously published for $\mathrm{Pb}$ isotopes in the Kulmerland region. The main objective of this research was to quantify anthropogenic $\mathrm{Pb}$ pollution over the last 1,500 years at Radzyń Chełmiński, using primarily $\mathrm{Pb}$ isotopic signatures. By comparing similar cores from two nearby sites (one in a rural area and a second in the vicinity of a town), we investigated short range (activity from a surrounding town) versus long 
range (mining signal from Southwestern Poland) transport pollution, as well as potential indirect climatic impacts on human development. Our combination of historical context with detailed geochemical data provide new insights about the extent of local and regional pollution dispersal.

\section{METHODOLOGY}

\section{$\underline{\text { 2.1 Study Sites }}$}

Two distinct ancient lake systems within the Chełmo Land, Kuyavian-Pomeranian Voivodeship, Poland were sampled for this study: Radzyń Chełmiński and Rywałd (Figure 1). The Kuyavian-Pomeranian Voivodeship lies along the border of historic Prussia and Poland. It came under Polish control from the mid-10th century and was at the frontier between Polish and Prussian territories. There were increasing raids by Prussians into the 12 th and early 13 th century in response to attempts by Poland to conquer Prussian territories, and eventually Konrad I Duke of Masovia invited in the Teutonic Order to help defend his territories in the early 1230s - with the first timber fortification built at Radzyn in 1234. Historical texts and archaeological studies indicate human settlement from the end of the Roman period (around 300 A.D.) to present (e.g. Pluskowski, 2013). The wetlands, including the Castle Lake, are now largely infilled and covered in sedges, with surface water present to ca. 10-20 cm within the interior of the lake, mostly during the wet winter/spring months.

The site at Radzyń Chełmiński lies within 300 m of Radzyń Chełmiński Castle, a Teutonic Order castle built between 1310 and 1340 A.D., and a town of approximately 2,000 inhabitants, settled in concurrence with the settlement of the Teutonic Order (early 13th century; Brown et al., 2015). The castle remained an important commander center into the 15 th century, 
but was dissolved in 1454 during the Thirteen Years War (1454-1466). By the 16th century much of the western wing of the castle was a disused ruin. The castle was partly dismantled in the 19 th century.

Rywałd, located $7 \mathrm{~km}$ due East of Radzyń Chełmiński, is a rural site with evidence of woodland, and minor human impact within the pollen record of the same core during the 11th to 12th centuries (Brown et al., 2015). The surrounding area only was used within the past century for agricultural purposes (Brown et al., 2015). The Vistula and Drwęca rivers are in proximity to both sites. The Vistula River runs through the center of the Voivodeship which was once the frontier zone between Slavic Pomeralia (East Pomerania), Prussian Pomesania, and Piast Poland (Brown and Pluskowski, 2011; Pluskowski, 2013; Zamoyski, 1987). The underlying sediment is made up of glacial till deposited by the Scandinavian ice sheet during the Vistulian (Weichselian) Glaciation (receded 11,700 years ago; Marks, 2012).

\subsection{Sampling}

Two sediment cores, $100 \mathrm{~cm}$ (Radzyń Chełmiński) and $120 \mathrm{~cm}$ (Rywałd) depth, were collected in August 2013 from the center of each wetland basin using a Russian auger. The

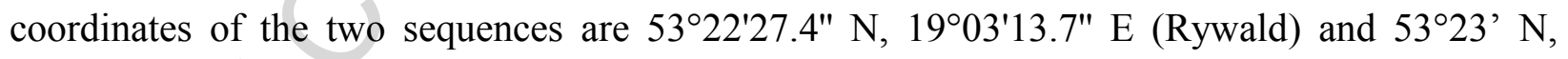
1856’ E (Radzyn). Sampling intervals were adjusted to obtain high-resolution records during the Crusading Period and Teutonic Order occupation focused on the late medieval period (13 ${ }^{\text {th }}$ to $16^{\text {th }}$ centuries) based on age models derived from radiocarbon dating. For Radzyń Chełmiński and Rywałd, 60 and 59 samples were considered, respectively. In March 2014, "background" samples of glacial sediment at 100-200 $\mathrm{cm}$ depth below land surface were collected adjacent to 
both lakes using a gouge auger to provide the natural background signature for each site. Four background samples for Radzyń were collected at Golebiewko, including 6 subsamples (N 53 degrees 23'39. 7" E 018 degrees 59'31. 1"). Three background samples for Rywałd were collected in Rywałd, including 9 subsamples (N 53 degrees 20'58.5" E 019 degrees 05'22.0"). All samples were stored at $4^{\circ} \mathrm{C}$ prior to analysis.

\section{$\underline{2.3 \text { Analyses }}$}

Sediment cores were logged to determine macroscopic lithofacies. Mastersizer Laser analysis was used to specify particle size within each macro layer. Samples were collected every $10 \mathrm{~cm}$ for each lithofacies section. Samples were placed on a plastic crucible where a minimal amount of Calgon solution was added and mixed into sample with a rubber stamper until all particles were separated. All organic material and particles above $2 \mathrm{~mm}$ were removed. The solution was washed with ultra-pure water into the Mastersizer Laser for analysis.

Extruded sediment samples dried at room temperature for three days, and homogenized with mortar and pestle prior to digestion. Aliquots of $500 \mathrm{mg}$ for each sample were transferred to digestion tubes and cold digested at room temperature for 12 hours using $10 \mathrm{ml}$ ultra-high purity $\mathrm{HNO}_{3}$ under clean lab conditions. Tubes were moved to hot baths and heated at $60^{\circ} \mathrm{C}$ for three hours, then at $110^{\circ} \mathrm{C}$ for an additional 12 hours. We wanted to extract metal deposition from the sediments bound to organic matter, metal that had adhered to particles as a result of atmospheric deposition and metals and elements bound to sediment surfaces. We did not want to digest all the inorganic, silicate material as this leads to a much more complex $\mathrm{Pb}$ isotope signal with the potential to mix from multiple geological sources. Studies have shown (Cook et al. 1997) that 
hot HNO3 digestion delivers similar results to other digestion techniques as the bulk of the metal concentration is absorbed to the mineral surfaces and/or in organic matter, not in the mineral silicate components. Digested samples were filtered using a $0.45 \mu \mathrm{m}$ filter and diluted to $100 \mathrm{ml}$ in ultra-pure water for analysis.

Reference materials (Sewage Reference 5RSS53) and full instrument blanks were included for all analyses. In order to quantify the recovery rates from our digestion methods we used an internal sewage sludge standard normalized against an international standard (ERM CC144), which has reported values for extractable metals in sewage sludge. The reason we chose these standards is that they have reported values for both total digestion and extractable metals (using nitric acid), and have relatively high TOC (36 wt \%) which was similar to the peaty, organic sediments from the core materials. The reported values for our internal standard (normalized to ERM CC144) for $\mathrm{Pb}$ were $118 \mathrm{mg} / \mathrm{kg}$ and $8.8 \mathrm{mg} / \mathrm{kg}$ for Ti. The average of our extracted values over four runs $(\mathrm{n}=8)$ were $128+/-13 \mathrm{mg} / \mathrm{kg}$ and $9.7+/-2.1 \mathrm{mg} / \mathrm{kg}$ for $\mathrm{Pb}$ and Ti respectively, resulting in a recovery of $108+/-9 \%$ and $111+-18 \%$, respectively. This indicates that the nitric acid extraction used was capable of liberating all of the available metal components in the organic fraction.

Lead and titanium concentrations were determined using a Perkin Optima 7300 Inductively Coupled Plasma - Optical Emission Spectrometer (ICP-OES) at the University of Reading, UK. For each depth horizon, the enrichment factor (E.F.) for $\mathrm{Pb}$ was calculated using the equation (1) provided below (Gloaguen and Passe, 2017; N'guessan et al., 2009) and average upper crustal $\mathrm{Pb}$ and $\mathrm{Ti}$ concentrations (McLennan, 2001). Enrichment Factor quantifies the amount of enrichment of $\mathrm{Pb}$ from natural levels within sediment (e.g. Chester and Stoner, 1973, N'guessan et al., 2009): 


$$
E F=\frac{\left(\frac{P b}{T i}\right)_{\text {sample }}}{\left(\frac{P b}{T i}\right)_{\text {upper continental crust }}}
$$

To determine $\mathrm{Pb}$ isotopic compositions, digested samples were further diluted to $4 \mathrm{ppb}$ of $\mathrm{Pb}$ for each sample, based on individual $\mathrm{Pb}$ concentrations per sample as quantified by ICP-OES, to maintain the same concentration throughout samples. This was done so that $\mathrm{Pb}$ concentration would not affect $\mathrm{Pb}$ isotope analysis. Reference NIST SRM 981 was used as the external standard for ${ }^{206} \mathrm{~Pb},{ }^{207} \mathrm{~Pb}$, and ${ }^{208} \mathrm{~Pb}$ measurements. All analyses were run in bracket configuration (standard-sample-standard) to allow for mass drift correction. Three Pb isotopes, namely ${ }^{206} \mathrm{~Pb}$, ${ }^{207} \mathrm{~Pb}$, and ${ }^{208} \mathrm{~Pb}$, were analyzed via Inductively Coupled Plasma - Mass Spectrometer (ICP-MS) (ThermoFisher iCapQ) equipped with a collision cell. The external calibration standard NIST SRM 981 was used to allow for mass drift correction. The mass drift for ${ }^{206} \mathrm{~Pb} /{ }^{207} \mathrm{~Pb}$ and ${ }^{208} \mathrm{~Pb} /{ }^{206} \mathrm{~Pb}$ were routinely $<0.5 \%$. Two $\mathrm{Pb}$ isotope ratios were calculated: ${ }^{206} \mathrm{~Pb} /{ }^{207} \mathrm{~Pb}$ and ${ }^{208} \mathrm{~Pb} /{ }^{206} \mathrm{~Pb}$. These ratios have been the most widely used in similar studies to determine anthropogenic inputs (e.g. Alfonso et al., 2001, Bi et al., 2017, Díaz-Somoano et al., 2009, Monna et al., 2000,).

\subsection{Sediment Dating}

Accelerator Mass Spectrometry (AMS) ${ }^{14} \mathrm{C}$ dating was used to determine absolute age and accumulation rates of sediment. Twelve samples were processed for Radzyń Chełmiński, at $10 \mathrm{~cm}$ intervals, with 10 samples taken from Rywałd, at 5-15 cm intervals. Samples for radiocarbon dating were sent to the Scottish Universities Research Centre (SUERC), Glasgow, Scotland. Linear regression modelling was conducted using Bayesian accumulation to provide 
age-to depth estimations through each core (SI_1; Bacon; Blaauw and Christen, 2011). To represent sediment dates, the notation "A.D." was used for the age.

Reliable chronologies are a fundamental component of palaeoecological investigation of lakes and peat bogs. Terrestrial plant macrofossils are considered the most reliable material for radiocarbon dating (Blaauw et al 2004), although unfortunately none were recovered from either Radzyń or Rywałd. Radiocarbon dates were therefore derived on samples of gyttja (Radzyń) and in the case of Rywałd on both peat and gyttja. Care was taken to identify any potential issues of contamination with old or young. Contamination by young carbon may occur through root penetration, whilst lake sediments may exhibit older radiocarbon ages (reservoir effect) reflecting inclusion of old carbon eroded from calcareous soils/bedrock, or through the uptake of dissolved inorganic carbon by aquatic plants (Björk and Wohlfarth 2004; Butz 2017).

Samples of bulk peat from Rywałd are derived from herbaceous fen considered reliable material for radiocarbon dating (e.g. Nilsson et al 2001; Blaauw et al 2004). The peat deposits reflect treeless habitats, although some herbaceous plants growing in fens, such as sedges, have root systems which can penetrate down to $2 \mathrm{~m}$, with the potential to introduce young carbon unless removed (e.g. Valiranta et al 2014). However, no roots or evidence for rooting by either trees or herbaceous plants was recorded during the detailed examination and sampling of the cores.

The core from Radzyń was the final of three cores (Radzyń 3) sampled and analysed from the Castle lake, with dates derived on gyttja (Radzyń 2 and Radzyń 3) and in the case of the first Radzyń core (Radzyń 1) on both peat and gyttja. Although the occurrence and/or magnitude of a reservoir effect can be difficult to determine without supporting dates from plant macrofossils or lake varves, comparison between the four lake sequences from Radzyń and 
Rywałd suggest that if present at all, the reservoir effect had a negligible effect on the chronologies. All four sequences show a strong linear progression in radiocarbon dates. There is a high degree of temporal similarity in pollen signals between sites, irrespective of whether dates are derived from peat or gyttja. Similarity is apparent in the timing of key changes in vegetation and land-use, most apparent in the decline in hornbeam, and the onset of major anthropogenic activity from c. AD 1100 (Brown 2019); these changes are considered to reflect comparable local-regional processes, reflected with varying magnitude in all four sequences from Radzyń and Rywałd. One could reasonably expect to observe spatial and temporal variations in the magnitude of a reservoir effect, reflecting variation in carbon input within and between sites and pollen sequences as a result of lake catchment, vegetation and land-use (e.g. Tranvik et al 2009; Shou et al 2015) The high degree of similarity therefore argues against a significant reservoir effect at Radzyń and Rywałd.

\subsection{Modelling}

The Bayesian mixing model Food Reconstruction Using Isotopic Transferred Signals (FRUITS; Fernandes et al., 2014) was run with our Pb isotope data $\left({ }^{206} \mathrm{~Pb} /{ }^{207} \mathrm{~Pb}\right.$ and ${ }^{208} \mathrm{~Pb} /{ }^{206} \mathrm{~Pb}$ ) to model the anthropogenic contribution (in $\%$ of total $\mathrm{Pb}$ ) versus time for both sites. Although FRUITS was made for dietary reconstruction, it is a general mixing model suitable for environmental isotopic modeling (e.g. Fernandes et al., 2014). FRUITS manual recommends to not using too many sources vs proxies, no more than +1 (i.e. if you have 2 isotope ratios, you shouldn't be asking FRUITS to attribute to more than 3 sources which is our case). For our modeling, natural endmembers comprised the mean background values specific to each site. The anthropogenic endmember for both sites was calculated from the mean of published Southwest 
Poland coal, ore, and slag lead isotopic signatures (Tyszka et al., 2012). The dust endmember for both sites was taken from Veron et al. (2014).

\section{RESULTS}

\subsection{Sediment Characterization}

Troel-Smith core logging results show sediment at Radzyń Chełmiński is composed of 1) highly humified Turfa herbacea and organic lake mud from 0 to $27 \mathrm{~cm}$ with a diffuse boundary; 2) organic lake mud with $10 \%$ to $1 \%$ roots from $27 \mathrm{~cm}$ to the bottom of the core. At Rywałd, sediment is composed of 1) Argilla granosa: silt with roots to partially humified Turfa herbacea peat from 0 to $43 \mathrm{~cm}$ with a sharp boundary; 2) silt and clay argilla with 5\% roots from 43 to 68 $\mathrm{cm}$ with a sharp boundary; 3) organic lake mud composed of silty sand to sandy silt from $87 \mathrm{~cm}$ to the bottom of the core (SI_2, SI_3).

According to particle size analyses and the Wentworth scale (Wentworth, 1922), Particle size for both sites ranged from 0.46 to 3080 microns, ranging in grain size class from fine clay to very fine gravel. The average grainsize at Radzyń Chełmiński was silt (55.56 to 62 microns) from 0 to about $30 \mathrm{~cm}$, and very fine sand (62 microns to 104 microns) from $30 \mathrm{~cm}$ to the bottom of the core. Percentages for clay, silt, and sand ranged from 0.67 to $3 \%, 50$ to $69 \%$, and 27 to 49\%, respectively. At Rywałd all sediment was very fine sand (62 to 125 microns) apart from 42 cm with an average particle size 126.25 microns (fine sand) (SI_4). Percentages for clay, silt, and sand ranged from 0.02 to $2 \%, 40$ to $61 \%$, and 23 to $50 \%$, respectively. 


\subsection{Lead Enrichment Factor and Isotopic Compositions}

Radzyń Chełmiński and Rywałd profiles for $\mathrm{Pb}$ enrichment factor relative to average continental crust (E.F.; McLennan, 2001), and ${ }^{206} \mathrm{~Pb} /{ }^{207} \mathrm{~Pb}$ are provided in Figure 2. Age values are based on the average age modelled by $2 \sigma$ Bayesian modelled uncertainties. Lead is enriched by a factor of 14 to 60, and 13 to 159 for Radzyń Chełmiński and Rywałd, respectively. At Rywałd, there is a sharp decrease from $\sim 150$ at the top of the core to 75 around A.D. 1980, then further decrease to a minimum $\mathrm{Pb}$ E.F. of 37 around A.D. 1755 \pm 147 . Lead enrichment factor at Rywałd then varies between 33 and 70 down to A.D. 1104 \pm 80 , increases to the maximum E.F. of 159 around A.D. $1024 \pm 94$, and steadily decreases to 14 (A.D. $731 \pm 109$ ), where the Pb E.F. becomes relatively stable around $15 \pm 2$ to the bottom of the core (A.D. 572 \pm 8 ). At Radzyń Chełmiński, Pb E.F. decreases from 81 at the top of the sediment core to 38 at A.D. $1621 \pm 166$, with a minor increase to 58 (A.D. $1587 \pm 148$ ) and continuing decrease to 30 at A.D. $1500 \pm 130$. Enrichment factor remains relatively stable with minor variations between 11 and 38 down to A.D. $979 \pm 102$, before decreasing to the minimum value of 14 at A.D. $894 \pm 85$, maintaining the same $\mathrm{Pb}$ E.F. until the bottom of the core (A.D. $803 \pm 99$ ).

For both sites, the ${ }^{206} \mathrm{~Pb} /{ }^{207} \mathrm{~Pb}$ ratio ranges from 1.17 to $1.27 \%$. At Radzyń Chełmiński, three zones can be defined. From the top of the core the ratio increases with age from $1.18 \%$ to $1.27 \%$ at A.D $1227 \pm 112$, then decreases to $1.18 \%$ at A.D. $934 \pm 97$. From this minimum, the ${ }^{206} \mathrm{~Pb} /{ }^{207} \mathrm{~Pb}$ ratio increases to $1.25 \%$ at the bottom of the core (A.D. $803 \pm 99$ ). Five ${ }^{206} \mathrm{~Pb} /{ }^{207} \mathrm{~Pb}$ zones can be identified for Rywałd. From the top of the core to A.D. $1443 \pm 114$, the isotopic ratio increases from $1.17 \%$ to $1.21 \%$, then remains constant at $1.21 \pm 0.05 \%$ o down to A.D. $1395 \pm 68$. The ${ }^{206} \mathrm{~Pb} /{ }^{207} \mathrm{~Pb}$ ratio continues to increase to $1.25 \%$ at A.D. $1253 \pm 44$, decreases to $1.18 \%$ at A.D. $1083 \pm 82$, remains constant at $1.18 \%$ to A.D. $768 \pm 106$, and significantly increases to 
$1.25 \%$ at A.D. $572 \pm 81$. These isotopic profiles are very different from those of previous published data of nearby sites from Northern Poland and Belgium (Fig. 2C; De Vleeschouwer et al., 2009b, Fagel et al., 2014), which show a similar trend to one another over time, with much lower and rather constant ${ }^{206} \mathrm{~Pb} /{ }^{207} \mathrm{~Pb}$ values $(1.14-1.18 \%$ ) than our new dataset.

From the top of both cores to about A.D. 1700 , as $\mathrm{Pb}$ E.F. decreases, the ${ }^{206} \mathrm{~Pb} /{ }^{207} \mathrm{~Pb}$ ratio increases. Lead E.F. and isotope ratios have a weak negative correlation, with higher Pb E.F.s coinciding with lower ${ }^{206} \mathrm{~Pb} /{ }^{207} \mathrm{~Pb}$ values.

\section{DISCUSSION}

\subsection{Identification of Lead Sources}

Three-point plots are a useful approach to differentiating among natural and anthropogenic $\mathrm{Pb}$ sources by comparing ${ }^{206} \mathrm{~Pb} /{ }^{207} \mathrm{~Pb}$ and ${ }^{208} \mathrm{~Pb} /{ }^{206} \mathrm{~Pb}$ ratios (Fig. 3; Alfonso et al., 2001, Bi et al., 2017, Díaz-Somoano et al., 2009, Harlavan et al., 2010, Monna et al., 2000, Zohar et al., 2014). Background sample averages from both sites (natural $\mathrm{Pb}$ isotopic ratio endmember: Radzyń Chełmiński: ${ }^{206} \mathrm{~Pb} /{ }^{207} \mathrm{~Pb}=1.33 \pm 0.01 \%$; ${ }^{208} \mathrm{~Pb} /{ }^{206} \mathrm{~Pb}=1.97 \pm 0.004 \%$; Rywałd: ${ }^{206} \mathrm{~Pb} /{ }^{207} \mathrm{~Pb}=1.30 \pm 0.02 \% ; ;{ }^{208} \mathrm{~Pb} /{ }^{206} \mathrm{~Pb}=1.96 \pm 0.03 \%$ ) and Southwest Poland coal, ore, and slag combined average (anthropogenic endmember: ${ }^{206} \mathrm{~Pb} /{ }^{207} \mathrm{~Pb}=1.17 \pm 0.01 \%$ and ${ }^{208} \mathrm{~Pb} /{ }^{206} \mathrm{~Pb}=2.09 \pm 0.01 \%$; Tyszka et al., 2012) were also included in Figure 3. Lead isotopic ratios for both Radzyń Chełmiński fall along a single trend line between the anthropogenic endmember and an endmember similar to the background averages. Due to the glacial till composition of background sediment, $\mathrm{Pb}$ isotopic ratios for samples are not perfectly linear with background ratios. Overall, the ${ }^{206} \mathrm{~Pb} /{ }^{207} \mathrm{~Pb}$ ratio ranges from 1.18 to $1.28 \%$ for Radzyń 
Chełmiński, and 1.17 to $1.25 \%$ for Rywałd. The ${ }^{208} \mathrm{~Pb} /{ }^{206} \mathrm{~Pb}$ ratio for Radzyń Chełmiński ranges from 1.96 to $2.08 \%$, and 1.98 to $2.10 \%$ for Rywałd. Error bars representing 1 standard deviation for all averages are included (Southern Poland coal, ore and slag ${ }^{206} \mathrm{~Pb} /{ }^{207} \mathrm{~Pb}=1.17 \pm 0.01$; ${ }^{208} \mathrm{~Pb} /{ }^{206} \mathrm{~Pb} \quad=2.09 \pm 0.01 ; \quad$ Radzyń Chełmiński background $\quad{ }^{206} \mathrm{~Pb} /{ }^{207} \mathrm{~Pb}=1.33 \pm 0.01$; ${ }^{208} \mathrm{~Pb} /{ }^{206} \mathrm{~Pb}=1.97 \pm 0.004$; Rywałd background ${ }^{206} \mathrm{~Pb} /{ }^{207} \mathrm{~Pb}=1.30 \pm 0.03 ;{ }^{208} \mathrm{~Pb} /{ }^{206} \mathrm{~Pb}=1.96 \pm 0.03$ ).

Compared to other similarly aged Central European sedimentary records, our new dataset displays significant differences (e.g. Fagel et al., 2014, Zillen et al., 2012, De Vleeschouwer et al., 2009b). Previously published data from the North Poland Bog (Słowińskie Błoto Bog; De Vleeschouwer et al., 2009b) fall along the same trend line. However, the North Poland bog displays an isotopic composition almost entirely from Southwest Poland coal and ore, indicating a much stronger regional anthropogenic signal, with little to no natural $\mathrm{Pb}$ input as indicated in the previous study (Fig. 3; De Vleeschouwer et al., 2009b). In addition, the North Poland Bog indicates an entirely anthropogenic source, with lower ${ }^{206} \mathrm{~Pb} /{ }^{207} \mathrm{~Pb}$ and ${ }^{208} \mathrm{~Pb} /{ }^{206} \mathrm{~Pb}$ than that of the Southwest Poland anthropogenic end members. Such source dissimilarity is expected. Unlike Radzyń Chełmiński and Rywałd, Słowińskie Błoto is a raised (ombrotrophic) peat bog. Signals from peat sediment are expected to record mostly atmospheric inputs (solely rain), versus lake sediment from the current study which include both terrestrial sediment (from runoff) and atmospheric inputs (e.g. Fagel et al., 2014, Thevenon et al., 2011).

\subsection{Changes in Lead Sources Over Time}

\subsubsection{Anthropogenic Sources}


Lead isotopic data processed using FRUITS, a Bayesian mixing model, quantified the importance of anthropogenic $\mathrm{Pb}$ inputs for each depth sampled (Fig. 4). Climatic periods included in bars below both graphs present cold periods as blue bars, and warm periods as red bars. Arrows along the top of Figure 4 indicate the building of a Teutonic Order fort (A.D. 1234; Urban, 1980) and castle (late $13^{\text {th }}$ century; Urban, 1980) at Radzyń Chełmiński; this activity would not have impacted Rywałd.

Modeled anthropogenic $\mathrm{Pb}$ contribution is described from oldest to most recent inputs (Fig. 4). At Radzyń Chełmiński, the fraction of total lead attributed to anthropogenic inputs in the oldest sediments appears to be influenced by anthropogenic Pb pollution from A.D. $883 \pm 99$ to A.D. $1054 \pm 104$. Contribution of Southwest Poland coal, ore, and slag during that period reaches a maximum of $35 \%$ at A.D. $979 \pm 97$. The anthropogenic fraction of total $\mathrm{Pb}$ remains below $1 \%$ from A.D. $1168 \pm 114$ to with A.D. $1296 \pm 94$, then increases from the beginning of the 14th century towards a dominantly anthropogenic contribution at the top of the core (up to 65\%).

At Rywałd, the modeled anthropogenic contribution increases from the core bottom to reach a maximum in A.D. $973 \pm 80$ of $65 \%$, and decrease to $1 \%$ at A.D. $1223 \pm 45$. Subsequently, the contribution sharply increases to $49 \%$ in A.D. $1303 \pm 54$ and remains relatively stable with an average value of $38 \pm 8 \%$ to the top of the core, with the exceptions of the two most recent samples (74 and 86\%).

\subsubsection{Mining Activity - Long Range Transport}

Atmospheric anthropogenic $\mathrm{Pb}$ signatures are expected to have been transported from regional mines. Approximately $400 \mathrm{~km}$ to the south of Radzyń Chełmiński and Rywałd, in the 
Rudawy Janowickie Mountains of Southwest Poland, a series of mines were active periodically over the last millennium (e.g. Kierczak and Pietranik, 2011). Primary ores from Southwest Poland include bituminous and brown coal, $\mathrm{Cu}, \mathrm{Zn}$, and $\mathrm{Pb}$ ores, native $\mathrm{S}$, and rock salt (Rybicka, 1996). Samples from Janowice, Wielkie, Szklary, Legnica, Miedzianka, and Wałbrzych sites in Southwest Poland were used to represent an anthropogenic contribution (Fig. 4; Tyszka et al., 2012). These mines are the nearest likely source of anthropogenic $\mathrm{Pb}$ in sediments from both Radzyń Chełmiński and Rywałd. Documentation and precise dates are scarce prior to the 1800 s, but evidence can be pieced together through the few historical records available and archaeological evidence.

First known $\mathrm{Zn}-\mathrm{Pb}$ ore exploitation in Southwest Poland began in the Cracow-Silesia district during the $12^{\text {th }}$ to $13^{\text {th }}$ centuries (Cabala et al., 2013). Mining and smelting of $\mathrm{Cu}$ in the Rudawy Janowickie Mountains has occurred from the $14^{\text {th }}$ century to present (e.g. Bukowski, 2011, Kierczak et al., 2013). Miedzianka, in particular was the largest center of mining and smelting $\mathrm{Cu}$, As, and Ag in Silesia, beginning as early as A.D. 1310 (Kierczak and Pietranik, 2011). These mining activities are probably responsible for the change in $\mathrm{Pb}$ isotopic ratios observed at Rywałd just after A.D. 1200 (Fig. 4). Copper slags were deposited in the mountains from the $14^{\text {th }}$ to $16^{\text {th }}$ century (Kierczak et al., 2013). Exploitation peaked in the $16^{\text {th }}$ century, when resources were exhausted, declining until the end of the $17^{\text {th }}$ century (Kierczak and Pietranik, 2011). Our data indicates that this historical record of mining activity resulted in lead pollution throughout the region, as shown by the relatively stable anthropogenic contribution in Rywałd for the same time period followed by a small decrease. Ore mining activities became prevalent again from the beginning of the $18^{\text {th }}$ century to the beginning of the $19^{\text {th }}$ century, focusing on $\mathrm{Cu}$-rich ore, as anthropogenic $\mathrm{Pb}$ again increases at Rywałd. Mining and smelting in 
the Rudawy Janowickie mountains ceased entirely in A.D. 1925 (Kierczak and Pietranik, 2011, Kierczak et al., 2013).

Coal exploitation was also prevalent in the Rudawy Janowickie Mountains of Southwest Poland from the $12^{\text {th }}$ century onwards, including two key basins, the Upper Silesian Coal Basin (Bukowski, 2011, Rybicka, 1996) and the Lower Silesian Coal Basin (LSCB; Rybicka, 1996). Ore was also mined in these basins. In Bytom and Olkusz, sub districts of the Upper Silesian Coal Basin, $\mathrm{Pb}, \mathrm{Zn}$, and $\mathrm{Cd}$ ores were mined since the $12^{\text {th }}-14^{\text {th }}$ century (depending on source; Ciarkowska et al., 2016, Rybicka, 1996,).

Additionally, from the 1800s onwards, anthropogenic contributions from modern mining, bituminous coal combustion, and leaded gasoline exerted substantial control of the sedimentary $\mathrm{Pb}$ isotopic compositions and concentrations at both sites, as documented in previous studies (e.g. De Vleeschouwer et al., 2009b, Fialkiewicz-Koziel et al., 2018).

To test our hypothesis, a simple mass-balance calculation was applied. At Radzyn by considering only the first $60 \mathrm{~cm}$ with a bulk density of approximately $1000 \mathrm{~kg} / \mathrm{m}^{3}$, where a mean increase in total $\mathrm{Pb}$ of about 5-10 ppm above baseline values can be observed, and by simplifying the time required to accumulate these sediments to 1000 years, we can estimate an average deposition rate of 3-6 mg. $\mathrm{m}^{-2} \mathrm{y}^{-1}$. Considering this range of deposition rate, we cannot exclude influences from other sources either local or distant.

\subsubsection{Land Use within Castle Lake Watershed - Short Range Transport}

Earliest palynological records at Radzyń Chełmiński suggest the region was dominated by woodland with evidence of local small-scale agricultural activities present around A.D. 0-700 
(Brown et al., 2015). The Wielbark culture was present in the area from the $2^{\text {nd }}$ to the $5^{\text {th }}$ century A.D., during the Migration period (A.D. 300 to 700 ). The $5^{\text {th }}$ to $9^{\text {th }}$ century is marked by archaeological evidence of tumuli and stone graves in the forest surrounding Radzyń Chełmiński, with remains of a Slavonic settlement adjacent to the forest (Samojlik et al., 2013). There is also archaeological evidence of depopulation from the $4^{\text {th }}$ century until Slavic settlement from the $7^{\text {th }}$ century (Buko, 2008). A Slavic stronghold was constructed in proximity to Castle Lake around the late $9^{\text {th }}$ century (e.g. Urban, 1980).

Prior to Teutonic settlement, the land surrounding Castle Lake at Radzyń Chełmiński was controlled by a Slavic Stronghold, occupied from the late $9^{\text {th }}$ to mid $12^{\text {th }}$ century when it may have been burnt down in an attack (Brown et al., 2015, Chudziak, 1994). Concurrently, there was an intensification in agricultural activity and decrease in woodland, causing increased soil erosion into the surrounding wetland, as presented by palynological evidence (Brown et al., 2015; Chudziak, 1996). Such erosion and increased land-use may have contributed to a decrease in recorded anthropogenic contribution and $\mathrm{Pb}$ concentration at Radzyń Chełmiński. Palynological evidence describes an increasingly open landscape in the pre-Crusading period $\left(11^{\text {th }}\right.$ to $12^{\text {th }}$ century) of both intensifying arable and pastoral activity, with woodland retained on nearby land (Brown et al., 2015).

Teutonic influence is documented at the location from A.D. 1234 to around A.D. 1454 when the Order ceded the territory to Polish control (Pluskowski, 2013; Urban, 1980). The Crusading period began in A.D. 1230, concurrent with the founding of the Teutonic Order castle and town at Radzyń Chełmiński (Brown et al., 2015). During this period agricultural and pastoral land-use was relatively stable surrounding the Castle Lake (Brown et al., 2015). A timber fort was constructed in A.D. 1234, and the castle was later built between A.D. 1310 and 1340 (e.g. 
Brown et al., 2015). Previously published palynological evidence from Radzyń Chełmiński recorded changes in vegetation and land use during this period, including a decrease in arboreal pollen and increase in cereal pollen (Brown and Pluskowski, 2011; Pluskowski, 2013). The period between A.D. 1350 and 1400 is known as the "Golden Age" of Teutonic Order influence (e.g. Pluskowski, 2013). Heathland developed along with agricultural intensification from the late $14^{\text {th }}$ to $15^{\text {th }}$ century, accompanied by a decrease in woodland area (Brown and Pluskowski, 2011). In addition to landscape changes with the arrival of the Teutonic Order, trade routes also developed by efforts to exploit Prussian resources, adding to human impact from the nearby settlements (Harte and Ponting, 1983). As the frontier land between Teutonic Order Prussia and Poland, the Chełmo land (Kulmerland in German), including Radzyń Chełmiński and Rywałd experienced intermittent raids from Prussian tribes, including the Great Prussian Uprising of the 1260s, and subsequent transformation of the landscape (Lukowski and Zawadzki, 2001; Pluskowski, 2013). Such agricultural intensification and castle building may have contributed to altered the regional anthropogenic isotopic signal from the opening of mines within the sediment records, minimizing the expected increase in anthropogenic $\mathrm{Pb}$ contribution that was detected at Rywałd, while at the same time causing an increase in $\mathrm{Pb}$ concentration.

In A.D. 1410, Radzyń Chełmiński Castle was damaged by Polish-Lithuanians (e.g. Pluskowski, 2013). From A.D. 1412 to 1439, the surrounding landscape was subjected to multiple seasons of crop failure, causing many villages in the area to be covered by woodland by A.D. 1444. The Thirteen Years war occurred shortly after, from A.D. 1453 to 1466, with many conflicts occurring near Radzyń, after which the castle became occupied by Poland (e.g. Pluskowski, 2013), falling into ruin by the $16^{\text {th }}$ century (Brown et al., 2015). Further damage occurred during the Swedish Invasion from A.D. 1626 to 1629 (e.g. Brown et al., 2015). Wooded 
areas contribute minimal weathered and eroded sediment to the surrounding basin, compared to predominantly open fields (arable and pastoral land). The decrease in local influence from the nearby castle and town, and re-establishment of woodlands, may have allowed for a return to a predominantly regional, atmospheric $\mathrm{Pb}$-derived signal in the sediment record during this period.

\subsubsection{Regional Climatic Influence}

Differentiating between climatic and historical influences remains challenging. Although $\mathrm{Pb}$ isotopes are not climate proxies, it is possible climate change or influencing meteorological conditions (e.g. change in dominant wind direction patterns, increase in rainfall, flood events, etc.) might indirectly influence $\mathrm{Pb}$ isotopic signatures by promoting the development of human activities (e.g. Büntgen et al., 2016, 2011), mostly during warmer and dryer periods. According to our sediment data (SI_2, SI_3), the Radzyń Chełmiński core is made entirely of lake mud/sediment; while Rywałd contains peat sediment from 0 to $68 \mathrm{~cm}$, and lake mud/sediment from $68 \mathrm{~cm}$ to the bottom of the core.

Sedimentary records for both cores span five climatic periods: 1) Late Antique Little Ice Age (LALIA, A.D. 536 to 660; e.g. Berglund et al., 2003; Büntgen et al., 2016); 2) the Climatic Optimum in Prussia (COP, A.D. 800 to 1150; e.g. Pluskowski, 2013); 3) the Medieval Warm Period (MWP; A.D. 800 to 1300; e.g. De Vleeschouwer et al., 2009b); 4) the Little Ice Age (LIA; A.D. 1300 to 1850; e.g. De Vleeschouwer et al., 2009b; Hegerl et al., 2017; Lockwood, 2001); and 5) Global Warming (GW; A.D. 1890 to present; e.g. Chiriloaei et al., 2012; Hegerl et al., 2017). Unlike in Western Europe, Prussian communities did not experience a regression after the medieval warm period, and instead thrived (Pluskowski, 2013). We hypothesize that 
promotion of human activities during favorable climatic conditions (Büntgen et al., 2016) included behaviors that mobilize lead, such as coal burning and ore utilization.

\section{CONCLUSION}

In this study, $\mathrm{Pb}$ concentrations and isotope ratios were used to quantify anthropogenic lead inputs and sources, as well as to identify trends in human activity in Northern Poland over the last 1,500 years. The use of a rural lake sediment core at Rywałd and a lake core influenced by a nearby town and Teutonic Order castle at Radzyń Chełmiński enabled differentiation between local and regional anthropogenic inputs.

Two primary $\mathrm{Pb}$ sources have been identified: (1) coal, ore, and slag originated from Southwestern Poland mining activities (long range transport); and (2) erosion from the surrounding watershed associated with the development of human activities (short range transport). High anthropogenic $\mathrm{Pb}$ contributions from the 9th to 11th centuries A.D., in the absence of historical evidence for mining activity in Southwestern Poland, point to a previouslyunrecognized, substantial anthropogenic pb source during that time period. Local activities dominated the $\mathrm{Pb}$ isotopic record from the $11^{\text {th }}$ to $13^{\text {th }}$ centuries A.D., during periods of Slavic and subsequent Teutonic Order settlement and castle building, and agricultural intensification. The long range, anthropogenic, mining signal was elevated around the $16^{\text {th }}$ and $18^{\text {th }}$ to $19^{\text {th }}$ centuries A.D., during periods of decreased local human agricultural activity.

Overall, the sediments at Rywałd recorded mostly long range mining inputs originating from Southwest Poland, while Radzyń Chełmiński sediments recorded both sources long range mining signal and local signal from an increase in agricultural and other human activities related 
to the development of the town and castle. Further studies are required to identify the sources responsible for the anthropogenic signal observed for our sites prior to A.D. 1000.

\section{ACKNOWLEDGMENTS}

The research leading to the results has received funding from the European Union's Seventh Framework Programme (FP7/2007-2013) under grant agreement no. 263735, The Ecology of Crusading. A.C. thanks the U.S. National Science Foundation (Award EAR1503596) for funding this research. A.C. acknowledges the Donors of the American Chemical Society Petroleum Research Fund (ACS-PRF 54583-DNI2) for supporting this research. We thank two anonymous reviewers for their constructive comments.

\section{REFERENCES}

Alfonso, S., Grousset, F., Masse, L., \& Tastet, J., 2001. A European lead isotope signal recorded from 6000 to 300 years BP in coastal marshes (SW France). Atmospheric Environment. 35, 3595-3605. https://doi.org/10.1016/s1352-2310(00)00566-5

Audry, S., Pokrovsky, O.S., Shirikova, L.S., Kirpoten, S.N., Dupre, B., 2011. Organic matter mineralization and trace element post-depositional redistribution in Western Siberia thermokarst lake sediments. Biogeosciences. 8, 3341-3358. https://doi.org/10.5194/bgd-8$8845-2011$ 
Baron, S., Carignan, J., Ploquin, A., 2006. Dispersion of Heavy Metals (Metalloids) in Soils from 800-Year-Old Pollution (Mont-Lozere, France). Environ. Sci. Technol. 40, 5319-5326. https://doi.org/10.1021/es0606430

Berglund, B.E., 2003. Human Impact and climate changes - synchronous events and a causal link? Quaternary International. 105, 7-12. https://doi.org/10.1016/s1040-6182(02)00144-1

Bi, X.-Y., Li, Z.-G., Wang, S.-X., Zhang, L., Xu, R., Liu, J.-L., Yang, H.-M., Guo, M.-Z., 2017. Lead Isotopic Compositions of Selected Coals, $\mathrm{Pb} / \mathrm{Zn}$ Ores and Fuels in China and the Application for Source Tracing. Environmental Science \& Technology. 51, 13502-13508. https://doi.org/10.1021/acs.est.7b04119

Bjőrck S., Wohlfarth, D., 2002. 14C chronostratigraphic techniques in paleolimnology, in: Smol J.P., Birks H.J.B., Last W.M., (eds.) Tracking Environmental Change Using Lake Sediments, vol 1.Kluwer Academic Publishers, Dordrecht, pp. 205-245.

Blaauw, M., van der Plicht, J., van Geel, B., 2004. Radiocarbon dating of bulk peat samples from raised bogs: non-existence of a previously reported 'reservoir effect'. Quat. Sci. Rev. 23, $1537-1542$.

Blaauw, M., Christen, J.A., 2011. Flexible Paleoclimate Age-Depth Models Using an Autoregressive Gamma Process. Bayesian Analysis. 6, 3, 457-474. https://doi.org/10.1214/11-BA618

Brown, A., Pluskowski, A., 2011. Detecting the environmental impact of the Baltic Crusades on a late-medieval (13th-15th century) frontier landscape: palynological analysis from Malbork 
Castle and hinterland, Northern Poland. Journal of Archaeological Science. 38(8), 19571966. https://doi.org/10.1016/j.jas.2011.04.010

Brown, A., Banerjea, R. Wynne, AD, Stivrins, N., Jarzebowski, M., Shillito, L-M., Pluskowski, A., 2015. The ecological Impact of conquest and colonization on a Medieval Frontier Landscape: Combined Palynological and Geochemical Analysis of Lake Sediments from Radzyń Chełmiński, Northern Poland. Geoarchaeology: An International Journal. 30, 511 527. https://doi.org/10.1002/gea.21525

Brown, A., 2019. Vegetation changes in Prussia: the palynological data. In A.G. Pluskowski (ed.) Environment, Colonisation, and the Crusader States in Medieval Livonia and Prussia. Brepols.

Buko, A., 2008. The archaeology of early medieval Poland: Discoveries - hypotheses interpretations. Leiden: Brill.

Bukowski, P., 2011. Water Hazard Assessment in Active Shafts in Upper Silesian Coal Basin Mines. Mine Water Environ. 30, 302-311. https://doi.org/10.1007/s10230-011-0148-2

Büntgen, U., Myglan, V.S., Ljungqvist, F.C., McCormick, M., Cosmo, N.D, Sigl, M., Jungclaus, J., Wagner, S., Krusic, P.J., Esper, J., Kaplan, J.O., de Vaan, M.A.C., Luterbacher, J., Wacker, L., Tegel, W., Kirdyanov, A.V., 2016. Cooling and societal change during the Late Antique Little Ice Age from 536 to around 660 AD. Nature Geoscience. 9, 231-236. https://doi.org/10.1038/ngeo2652 
Büntgen, U., Tegel, W., Nicolussi, K., McCormick, M., Frank, D., Trouet, V., Kaplan, J.O., Herzig, F., Heussner, K.-U., Wanner, H., Luterbacher, J., Esper, J., 2011. 2500 Years of European Climate Variability and Human Susceptibility. Science, 331, 578-582. https://doi.org/10.1126/science.1197175

Butz, C., Grosjean, M., Goslar, T., et a., 2017. Hyperspectral imaging of sedimentary bacterial pigments: a 1700-year history of meromixis from varved Lake Jaczno, northeast Poland. J. Palaeolimnol. 58, 57-72.

Cabala, J. Smieja-Krol, B., Jablonska, M., Chrost, L., 2013. Mineral components in a peat deposit: looking for signs of early mining and smelting activities in Silesia-Cracow region (Southern Poland). Environ. Earth Sci. 69, 2559-2568. https://doi.org/10.1007/s12665-012-2080-6

Cheng, H., Hu, Y., 2010. Lead (Pb) isotopic fingerprinting and its applications in lead pollution studies in China: A review. Environmental Pollution. 158,5, 1134-1146. https://doi.org/10.1016/j.envpol.2009.12.028

Chester, R., Stoner, J.H., 1973. Pb in particulates from the lower atmosphere of the eastern Atlantic. Nature. 24, 27-28. https://doi.org/10.1038/245027b0

Chiriloaei, F., Rădoane, M., Perşoiu, I., Popa, I., 2012. Late Holocene history of Moldova River Valley, Romania. Catena. 93, 64-77. https://doi.org/10.1016/j.catena.2012.01.008

Chudziak, W., 1996. Zasiedlenie strefy chełmin' sko-dobrzyn’ skiej we wczesnym s'redniowieczu (VII-XI wiek). Torun': UMK. 
Ciarkowska, K., Gargiulo, L., Mele, G., 2016. Natural restoration of soils on mine heaps with similar technogenic parent material: A case study of long-term soil evolution in SilesianKrakow Upland Poland. Geoderma. 261, 141-150. https://doi.org/10.1016/j.geoderma.2015.07.018

Cook, J.M., Gardner, M.J., Griffiths, A.H., Jessop, M.A., Ravenscroft, J.E. and Yates, R. (1997) The comparability of sediment digestion techniques for the determination of metals in sediments. Marine Pollution Bulletin, 34(8), 637-644.

De Vleeschouwer, F., Piotrowska, N., Sikorski, J., Pawlyta, J., Cheburkin, a., Le Roux, G., Lamentowicz, M., Fagel, M., Mauquoy, D., 2009a. Multiproxy evidence of 'Little Ice Age’ palaeoenvironmental changes in a peat bog from northern Poland. The Holocene. 19, 4, 625-637. https://doi.org/10.1177/0959683609104027

De Vleeschouwer, F., Fagel, N., Cheburkin, A., Pazdur, A., Sikorski, J., Mattielli, N., Renson, V., Fialkiewicz, B., Piotrowska, N., Le Roux, G., 2009b. Anthropogenic impacts in North Poland over the last 1300 years - A record of $\mathrm{Pb}, \mathrm{Zn}, \mathrm{Cu}, \mathrm{Ni}$ and $\mathrm{S}$ in an ombrotrophic peat bog. Science of the Total Environment. 407(21), 5674-5684. https://doi.org/10.1016/j.scitotenv.2009.07.020

Díaz-Somoano, M., Kylander, M.E., López-Antón, M.A., Suárez-Ruiz, M.R., Martínez-Tarazona, M., Ferrat, Kober, B., Weiss, D.J., 2009. Stable Lead Isotope Compositions In Selected Coals From Around The World And Implications For Present Day Aerosol Source Tracing. Environ. Sci. Technol. 43, 1078-1085. 
Doe, B. R., 1970. Lead isotopes. Springer Verlag, Berlin, Heidelberg, New York. https://doi.org/10.1007/978-3-642-87280-8

Fagel, N., Allan, M., Le Roux, G., Mattielli, N. Piotrowska, N., Sikorski, J., 2014. Deciphering human-climate interactions in an ombrotrophic peat record: $\mathrm{REE}, \mathrm{Nd}$ and $\mathrm{Pb}$ isotope signatures of dust supplies over the last 2500years (Misten bog, Belgium). Geochimica et Cosmochimica Acta. 135, 288-306. https://doi.org/10.1016/j.gca.2014.03.014

Fernandes, R., Millard, A. R., Brabec, M., Nadeau, M.-J., \& Grootes, P., 2014. Food Reconstruction Using Isotopic Transferred Signals (FRUITS): A Bayesian Model for Diet Reconstruction. PLoS ONE. 9,2. https://doi.org/10.1371/journal.pone.0087436

Fiałkiewicz-Kozieł, B., De Vleeschouwer, F., Mattielli, N., Fagel, N., Palowski, B., Pazdur, A., Smieja-Król, B., 2018. Record of Anthropocene pollution sources of lead in disturbed peatlands from Southern Poland. Atmospheric Environment. 179, 61-68. https://doi.org/10.1016/j.atmoseny.2018.02.002

Flegal, A.R., Smith, D.R., 1995. Measurements of environmental lead contamination and human exposure. Reviews of Environmental Contamination and Toxicology. 143, 1-45. https://doi.org/10.1007/978-1-4612-2542-3_1

Gallon, C., Tessier, A., Gobeil, C., Afaro-De La Torre, M. C., 2004. Modeling diagenesis of lead in sediments of a Canadian Shield Lake. Geochimica et Cosmochimica Acta. 68,17, 35313545. https://doi.org/10.1016/j.gca.2004.02.013 
Grousset, F.E., Quetel, C.R., Thomas, B., Buatmenard, P., Donard, O.F.X., Bucher, A., 1994. Transient $\mathrm{Pb}$ Isotopic Signatures in the Western-European Atmosphere. Environ. Sci. Technol. 28, 9, 1605-1608. https://doi.org/10.1021/es00058a011

Harlavan, Y., Erel, Y., Blum, J. D., 1998. Systematic Changes in Lead Isotopic Composition with Soil Age in Glacial Granitic Terrains. Geochimica et Cosmochimica Acta. 62,1, 33-46. https://doi.org/10.1016/s0016-7037(97)00328-1

Harlavan, Y., Almogi-Labin, A., Herut, B., 2010. Tracing Natural and Anthropogenic Pb in Sediments along the Mediterranean Coast of Israel using $\mathrm{Pb}$ Isotopes. Environ. Sci. Technol. 44, 6576-6582. https://doi.org/10.1021/es9039055

Harte, N.B. \& Ponting, K.G. (Eds), 1983. Cloth and Clothing in Medieval Europe: Essays in Memory of Professor E.M. Carus-Wilson. Heinemann Educational Books Ltd., London.

Hegerl, G. C., Brönnimann, S., Schurer, A., Cowan, T., 2017. The early 20th century warming: Anomalies, causes, and consequences. WIREs Clim. Change. 9, e522. https://doi.org/10.1002/wcc.522.

Hosono, T., Alvarez, K., Kuwae, M., 2016. Lead isotope ratios in six lake sediment cores from Japan Archipelago: Historical record of trans-boundary pollution sources. Science of the Total Environment. 559, 24-37. https://doi.org/10.1016/j.scitotenv.2016.03.138

Huerta-Diaz, M. A., Tessier, A., Carignan, R., 1998. Geochemistry of trace metals associated with reduced sulfur in freshwater sediments, Applied Geochemistry. 13, 213-233. https://doi.org/10.1016/s0883-2927(97)00060-7 
Kierczak, J., Pietranik, A., 2011. Mineralogy and composition of historical Cu Slags from the Rudawy Janowickie Mountains, Southwestern Poland. The Canadian Mineralogist. 49, 1281-1296. https://doi.org/10.3749/canmin.49.5.1281

Kierczak, J., Potysz, A., Pietranik, A., Tyszka, R., Modelska, M., Néel, C., Ettler, V., Mihaljevič, M., 2013. Environmental impact of the historical $\mathrm{Cu}$ smelting in the Rudawy Janowickie Mountains (south-western Poland). J. Geochemical Exploration. 124, 183-194. https://doi.org/10.1016/j.gexplo.2012.09.008

Komárek, M., Ettler, V., Chrastný, V., Mihaljevič, M., 2008. Lead isotopes in environmental sciences: A review. Environment International. 34, 4, 562-577. https://doi.org/10.1016/j.envint.2007.10.005

Kylander, M., Weiss, D., Martinezcortizas, A., Spiro, B., Garciasanchez, R., Coles, B., 2005. Refining the pre-industrial atmospheric $\mathrm{Pb}$ isotope evolution curve in Europe using an 8000 year old peat core from NW Spain. Earth and Planetary Science Letters. 240, 2, 467-485. https://doi.org/10.1016/j.epsl.2005.09.024

Lanphear, B.P., Hornung, R., Khoury, J., Yolton, K., Baghurst, P., Bellinger, D.C., Canfield, R.L., Dietrich, K.N., Bornschein, R., Greene, T., Rothenberg, S.J., Needleman, H.L., Schnaas, L., Wasserman, G., Graziano, J., Roberts, R., 2005. Low-Level Environment Lead Exposure and Children's Intellectual Function: An International Pooled Analysis. Environmental Health Perspectives, 113, 7, 894-899.

Lockwood, J.G., 2001. Abrupt and sudden climatic transitions and fluctuations: A Review. Int. J. Climatol. 21, 9, 1153-1179. https://doi.org/10.1002/joc.630.abs 
Lukowski, J. \& Zawadzki, H., 2001. A Concise History of Poland. Cambridge University Press, Cambridge. https://doi.org/10.1017/cbo9780511813856

Marks, L., 2012. Timing of the Late Vistulian (Weichselian) glacial phases in Poland. Quaternary Science Reviews. 44, 81-88. https://doi.org/10.1016/j.quascirev.2010.08.008

Martínez Cortizas, A., García-Rodeja, E., Pontevedra Pombal, X., Nóvoa Muñoz, J.C., Weiss, D., Cheburkin, A., 2002. Atmospheric Pb deposition in Spain during the Last 4600 years recorded by two ombrotrophic peat bogs and implications for the use of peat as archive. Sci. Total. Environ. 292, 33-44.

Martínez Cortizas, A., López-Merino, L., Bindler, R., Mighall, T., Kylander, M.E., 2016. Early atmospheric metal pollution provides evidence for Chalcolithic/Bronze Age mining and metallurgy in Southwestern Europe. Sci. Total. Environ. 545-546, 398-406. http://dx.doi.org/10.1010/j/scitotenv.2015.12.078

McIntyre, A.M., Gueguen, C., 2013. Binding interactions of algal-derived dissolved organic matter with metal ions. Chemosphere. 620-626. https://doi.org/10.1016/j.chemosphere.2012.08.057

McLennan, S.M., 2001. Relationships between the trace element composition of sedimentary rocks and upper continental crust. Geochemistry, Geophysics, Geosystems. 2, 4, 2000GC000109. https://doi.org/10.1029/2000gc000109

Mil-Homens, M., Caetano, M., Costa, A. M., Lebreiro, S., Richter, T., de Stigter, H., Johnson, M., Branco, V., Cesario, R., Mouro, F., Mateus, M., Boer, W., Melo, Z., 2013. Temporal 
evolution of lead isotope ratios in sediments of the Central Portuguese Margin: A fingerprint of human activities. Marine Pollution Bulletin. 74, 1, 274-284. https://doi.org/10.1016/j.marpolbul.2013.06.044

Mil-Homens, M., Vale, C., Brito, P., Naughton, F., Drago, T., Raimundo, J., Anes, B., Schmidt, S., Caetano, M., 2017. Insights of $\mathrm{Pb}$ isotopic signature into the historical evolution and sources of $\mathrm{Pb}$ contamination in a sediment core of the southwestern Iberian Atlantic shelf. Sci Total Environ. 586, 473-484.

Monna, F., Hamer, K., Lévêque, J., Sauer, M., 2000. Pb isotopes as a reliable marker of early mining and smelting in the Northern Harz province (Lower Saxony, Germany). Journal of Geochemical Exploration. 68, 201-210. https://doi.org/10.1016/s0375-6742(00)00005-4

Nilsson, M., Klarqvist, M., Bohlin, E., et al., 2001. Variation in 14C age of macrofossils and different fractions of minute peat samples dated by AMS. The Holocene 11, 579-586.

Novák, M., Emmanuel, S., Vile, M., Erel, Y., Véron, A., Pačes, T., Wieder, R.K., Vanecek, M., Stepanova, M., Brizova, E., Hovorka, J., 2003. Origin of lead in eight European peat bogs determined from isotope ratios, strengths, and operation times of regional pollution sources. Environ. Sci.Technol. 37, 437-45. https://doi.org/10.1021/es0200387

Noryśkiewicz, A.M., 2004. Przemiany w szacie ro'slinnejokolic Us'cia w okresie ostatnich dwo' ch tysie cy lat. In W. Chudziak (Ed.), Wczesnos'redniowieczny zespo' $\nmid$ osadniczy Kałdusie. Studia przyrodniczo archeologiczne. 151-163. 
Noryśkiewicz, A.M., 2005. Preliminary results of study on vegetation history in the Linje mire region using pollen analysis. Monographiae Botanicae. 94, 118-133.

Pluskowski, A., 2013. The Archaeology of the Prussian Crusade: Holy War and colonization. Routledge, Abington, UK. https://doi.org/10.4324/9780203079867

Reimann, C., Flem, B., Fabian, K., Birke, M., Ladenberger, A., Négrel, P., Demetriades, A., Hoogewerff, J., The Gemas Project Team, 2012. Lead and lead isotopes in agricultural soils of Europe - The continental perspective. Applied Geochemistry 27, 3, 532-542. https://doi.org/10.1016/j.apgeochem.2011.12.012

Russell, R.D., Farquhar, R.M., 1960. Lead Isotopes in Geology. Interscience Publishers, New York.

Rybicka, E.H., 1996. Impact of mining and metallurgical industries on the environment in Poland. Applied Geochemistry. 11, 3-9. https://doi.org/10.1016/0883-2927(95)00083-6

Samojlik, T.; Rotherham, I. D.; Jedrzejewska, B., 2013. Quantifying Historic Human Impacts on Forest Environments: A Case Study in Bialowieza Forest, Poland. Environmental History. 18, 3, 576-602. https://doi.org/10.1093/envhis/emt039

Schultz, M.F., Benjamin, M.M., Ferguson, J.F., 1987. Adsorption and desorption of metals on ferrihydrite: reversibility of the reaction and sorption properties of the regenerated solid. Environ. Sci. Technol. 21, 863-869. https://doi.org/10.1021/es00163a003

Shotyk, W., 1998. History of Atmospheric Lead Deposition since 12,370 14C yr. BP from a Peat Bog, Jura Mountains, Switzerland. Science. 281, 5383, 1635-1640. https://doi.org/10.1126/science.281.5383.1635 
Szal, M., Kupryjanowicz, M. Wyczolkowski, M., Tylmann, W., 2014. The Iron Age in the Mrągowo Lake District, Masuria, NE Poland: The Salet settlement microregion as an example of long-lasting human impact on vegetation. Vegetation History and Archaeobotany. 23, 419-437.

Tessier, A., Fortin, D., Belzile, N., Dévitré, R.R., Leppard, G.G., 1996. Metal sorption to diagenetic iron and manganese oxyhydroxides and associated organic matter: Narrowing the gap between field and laboratory measurements. Geochimica et Cosmochimica Acta. 60, 3, 387404. https://doi.org/10.1016/0016-7037(95)00413-0

Thevenon, F., Graham, N.D., Chiaradia, M., Arpagaus, P., Wildi, W., Pote, J., 2011. Local to regional scale industrial heavy metal pollution recorded in sediments of large freshwater lakes in central Europe (lakes Geneva and Lucerne) over the last centuries. Sci. Tot. Environ. 412-413, 239-247. https://doi.org/10.1016/j.scitotenv.2011.09.025

Tranvik, L.J., Downing, J.A.., Carter, J.B., et al., 2009. Lakes and reservoirs as regulators of carbon cycling and climate. Limnol. Oceanog. 54, 2298-2314.

Tyszka, R., Pietranik, a., Kierczak, J., Ettler, V., Mihaljevič, M., Weber, J., 2012. Anthropogenic and lithogenic sources of lead in Lower Silesia (Southwest Poland): An isotope study of soils, basement rocks and anthropogenic materials. Applied Geochemistry. 27, 6, 10891100. https://doi.org/10.1016/j.apgeochem.2012.02.034

Urban, W., 1980. The Prussian Crusade. University Press of America, Inc. London, England. 
Verner, J.F., Ramsey, M.H., Helios-Rybicka, E., Jedrzejczyk, B., 1996. Heavy metal contamination of soils around a $\mathrm{Pb}-\mathrm{Zn}$ smelter in Bukowno, Poland. Applied Geochemistry. 11, 11-16. https://doi.org/10.1016/0883-2927(95)00093-3.

Véron, A., Novak, M., Brizova, E., Stepanova, M., 2014. Environmental imprints of climate changes and anthropogenic activities in the Ore Mountains of Bohemia (Central Europe) since 13 cal. Kyr. BP. The Holocene. 24, 8, 919-931. https://doi.org/10.1177/0959683614534746

Wentworth, C.K., 1922. A scale of grade and class terms for clastic sediments. The Journal of Geology. 30, 5, 377-392. https://jstor.org/stable/30063207

Zaborska, A., 2014. Anthropogenic lead concentrations and sources in Baltic Sea sediments based on lead isotopic composition. Marine Pollution Bulletin. 85, 1, 99-113. https://doi.org/10.1016/j.marpolbul.2014.06.013

Zamoyski, A., 1987. The Polish Way: A thousand year history of the poles and their culture. John Murray Ltd, Great Britain.

Zhou, A., Yuxin, H., Shang, X., et al., 2015. Changes in the radiocarbon reservoir age in Lake Xingyun, southwestern China during the Holocene. PLoS One 10, 1-21.

Zillen, L., Lenz, C., Jilbert, T., 2012. Stable lead (Pb) isotopes and concentrations - A useful independent dating tool for Baltic Sea sediments. Quaternary Geology. 8, 41-45. https://doi.org/10.1016/j.quageo.2011.11.001 
Zohar, I., Bookman, R., Levin, N., de Stigter., H., Teutsch, N., 2014. Contamination History of Lead and Other Trace Metals Reconstructed from an Urban Winter Pond in the Eastern Mediterranean Coast (Israel). Environ. Sci. Technol. 48, 13592-13600. https://doi.org/10.1021/es500530x 


\section{Figure captions}

Figure 1: Site Map. A) Central and Eastern Europe, B) Location of the Kulmerland within Medieval Prussia, including lands controlled by the Teutonic Order, C) The Kulmerland region including (1) Radzyń Chełmiński core, Radzyń Chełmiński Castle, and (2) Rywałd core (modified from Brown et al., 2015).

Figure 2: Sedimentary profiles of $\mathrm{Pb}$ enrichment factors (E.F., left panel), ${ }^{206} \mathrm{~Pb} /{ }^{207} \mathrm{~Pb}$ $(\%)$ isotopic ratios for Radzyń Chełmiński and Rywałd (middle panel, the vertical light purple represents the ${ }^{206} \mathrm{~Pb} /{ }^{207} \mathrm{~Pb}$ isotopic signature of the background, i.e. underneath earth material layer), and previously published profiles (right panel) from a bog located in Northern Poland (De Vleeschower et al., 2009) and a Belgian Peatland (Fagel et al., 2014).

Figure 3: ${ }^{206} \mathrm{~Pb} /{ }^{207} \mathrm{~Pb}$ and ${ }^{208} \mathrm{~Pb} /{ }^{206} \mathrm{~Pb}$ isotopic ratio three-point plot. Red dots, blue dots, green squares, open orange circle, open red triangle and open blue triangle represent Radzyń Chełmiński, Rywałd, Slowinskie Blota Bog (De Vleeschower et al., 2009), Poland ore, slag, coal (Tyszka et al., 2012), Radzyń Chełmiński background and Rywałd background, respectively.

Figure 4: Source contribution -dust, natural and anthropogenic-(top panel for Radzyń Chełmiński and third panel for Rywałd) and Pb concentration (second panel for Radzyń Chełmiński and bottom panel for Rywałd) versus time (horizontal bottom axis). Source contribution was calculated using a Bayesian code (FRUITS) using ${ }^{206} \mathrm{~Pb} /{ }^{207} \mathrm{~Pb} \%$ and ${ }^{208} \mathrm{~Pb} /{ }^{206} \mathrm{~Pb} \%$. See main text for detailed explanation about the modeling. Horizontal bars (blue and red) below the plot displays climatic periods. Late Antique Little Ice Age (LALIA, 536 to 660 AD; left blue bar). Climatic Optimum in Prussia (COP, 800 to 1150 $A D$; light red bar on the top). Medieval Warm Period (MWP; 800 to 1300 AD; left red bar). Little Ice Age (LIA; 1300 to 1850 AD; right blue bar). Global Warming (GW; 1890 to present; right red bar). Vertical arrows are only relevant to Radzyń Chełmiński and represent the Teutonic timber fort built (1234 AD; Urban, 1980) and the Radzyń Chełmiński Castle Built (late $13^{\text {th }}$ century; Urban, 1980), respectively. 


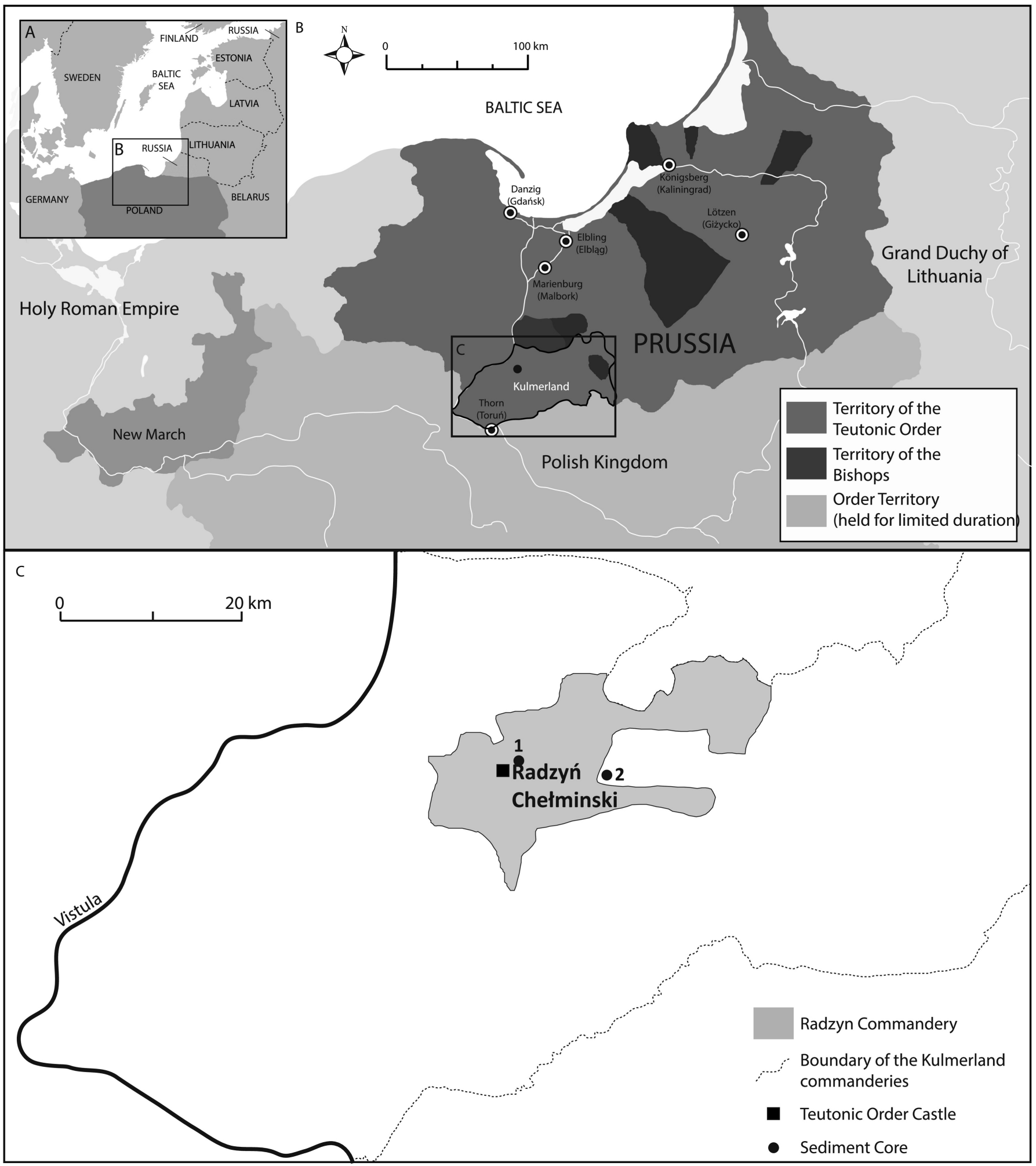

Figure 1 


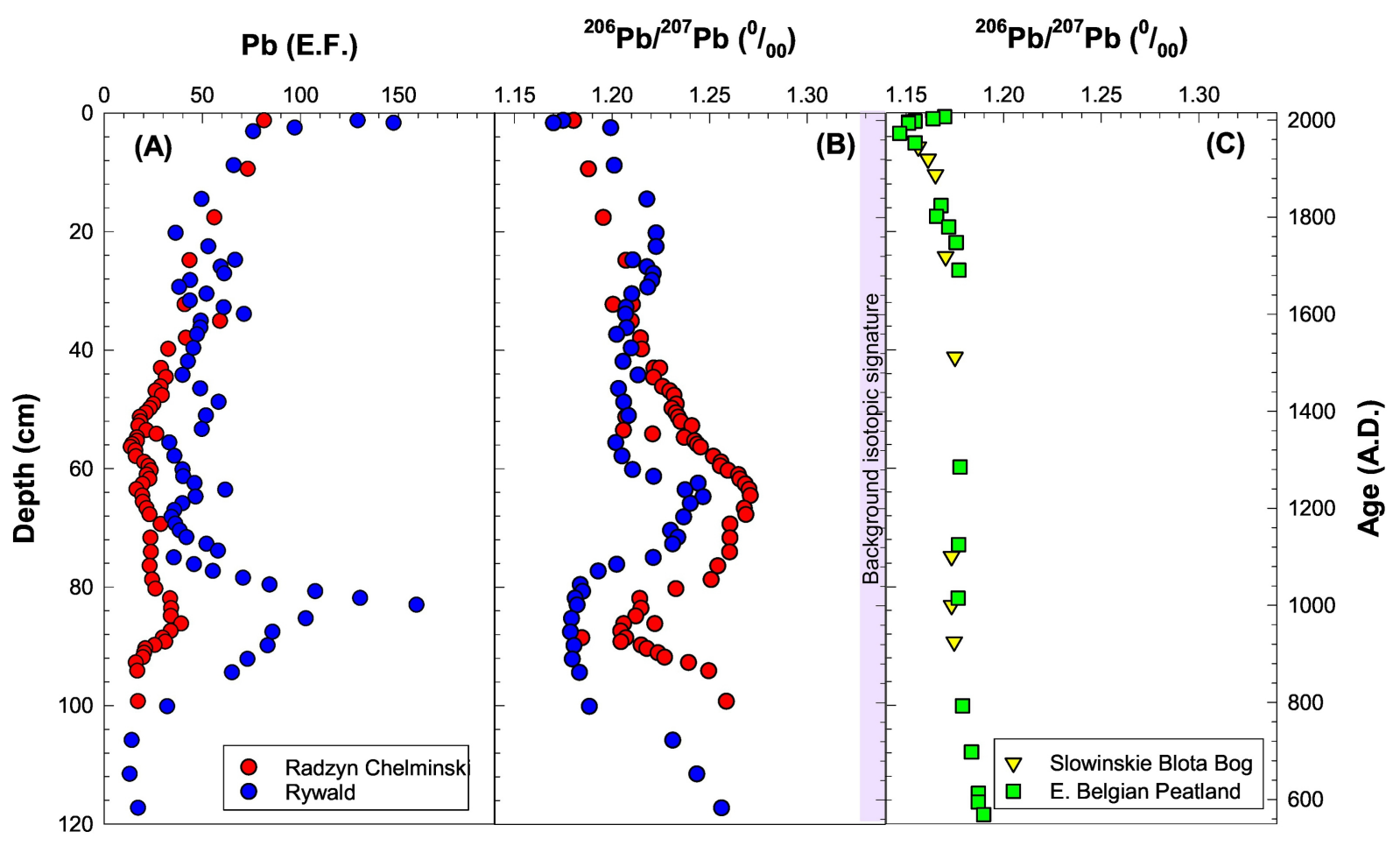

Figure 2 


\section{${ }^{206} \mathrm{~Pb} /{ }^{207} \mathrm{~Pb}\left({ }^{0} /_{00}\right)$}

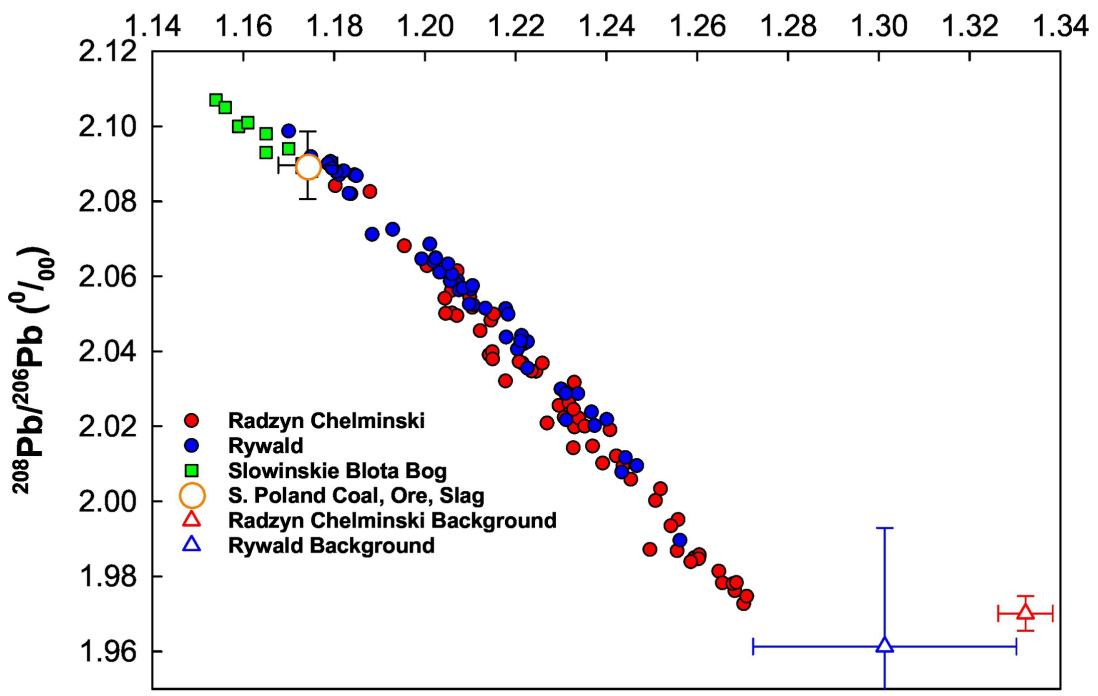

Figure 3 

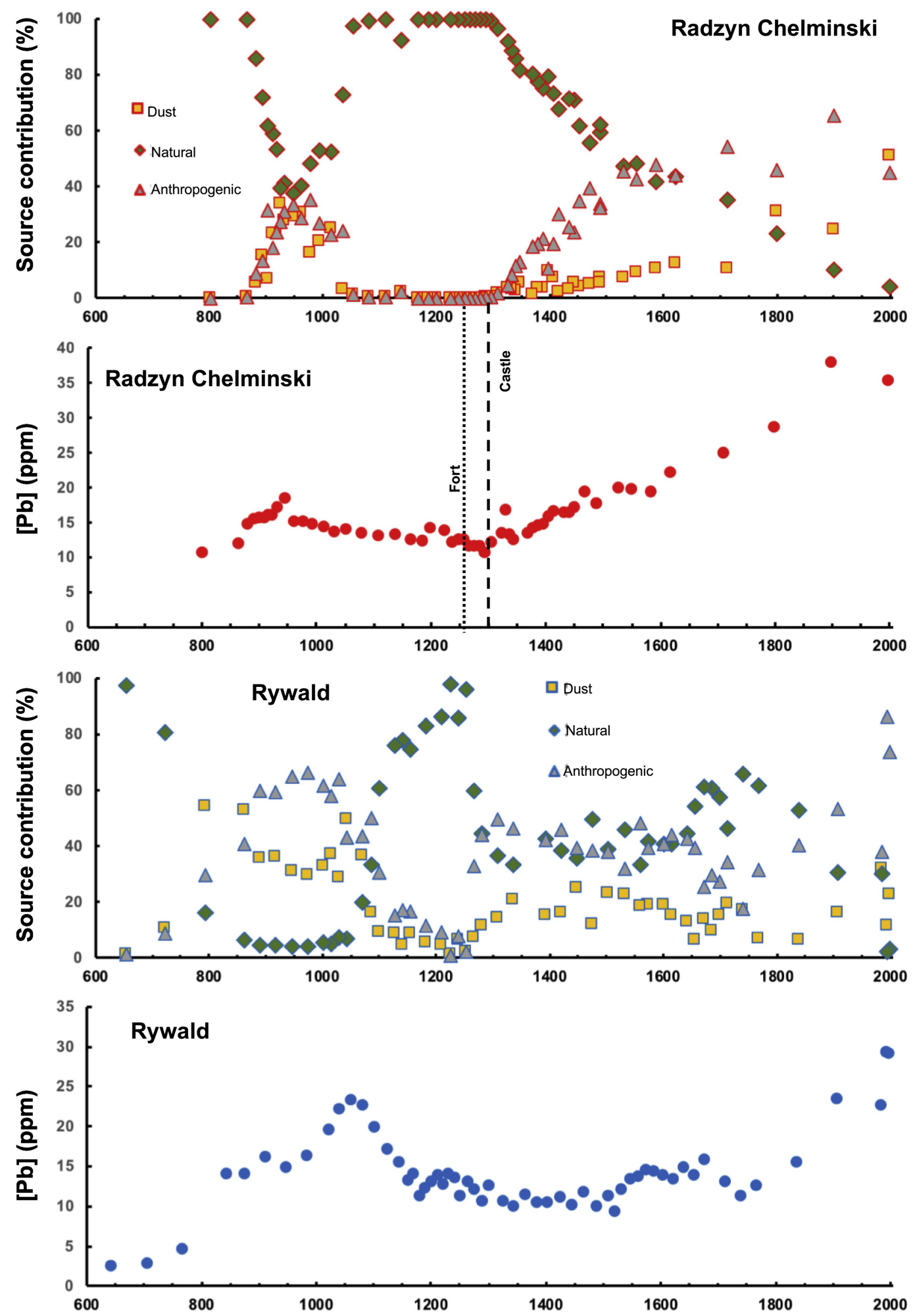

Age (A.D.) 